\title{
Spermatogenesis in testes of Dazl null mice after transplantation of wild-type germ cells
}

\author{
Rilianawati $^{1}$, R. Speed ${ }^{2}$, M. Taggart ${ }^{2}$ and H. J. Cooke ${ }^{2 *}$ \\ ${ }^{1}$ Fakultas Kedokteran Universitas Sriwijaya, Jalan Mayor Mahidin KM3, 5 Kompleks RSU, Palembang, \\ Indonesia; and ${ }^{2}$ MRC Human Genetics Unit, Western General Hospital, Crewe Road, Edinburgh EH4 2XU, UK
}

\begin{abstract}
Dazl knockout male mice are infertile because their germ cells are unable to complete the first meiotic prophase in the first wave of spermatogenesis and thereafter decrease in number due to a block at the A-aligned to A1 transition. The ability of the surviving somatic components of the testes to retain their function in the absence of mature germ cells was tested by injecting marked wild-type germ cell suspensions containing spermatogonial stem cells. Comparison of the frequency and extent of colonization
\end{abstract}

of Dazl knockout testes with that of testes chemically depleted of germ cells showed little if any difference. It was concluded that Dazlko testes seem unimpaired in their ability to support spermatogenesis. Therefore, Dazlko testes provide a useful and reliable recipient in which to evaluate spermatogonial stem cells. The results furthermore demonstrate that the somatic compartment of the testis of these animals retains functionality.

\section{Introduction}

Spermatogenesis depends upon the tight collaboration between germline and somatic cells. This is apparent at a number of levels from the histological level, where a very controlled spatial organization is evident, to the endocrine level, where testosterone is synthesized in the interstitial Leydig cells. Within the seminiferous epithelium the germ cells develop in close association with the somatic Sertoli cells which provide structural and functional support. Male factor infertility can arise from malfunction in either somatic or germline component and an example of this is provided by studies on mutants with deficiencies in expression of the steel ligand (Sertoli cell product) or its receptor c-kit (expressed on germ cells) resulting in infertility (Nakayama et al., 1988; Ogawa et al., 2000). Recently, increased attention has been paid to genetic problems leading to germ cell failure in men. A particular focus has been on $\mathrm{Y}$ chromosome deletions; de novo deletions are present in about $10 \%$ of azoospermic men and represent the largest single genetic cause of infertility. It is commonly considered that there are three deletion regions, termed AZFa, b and c; the most frequently deleted region, AZFC, contains over 20 potential transcription units including four copies of the Deleted in AZoospermia gene, $D A Z$, which was the first gene found in this region. Deletions of this region are associated with variable phenotypes (Reijo et al., 1995). The basic cellular defect in cases of human male infertility is difficult to dissect for a variety of reasons,

${ }^{*}$ Correspondence

Email: howard.cooke@hgu.mrc.ac.uk most notably because the development of the testis has not been monitored during development and therefore the phenotype observed when the individual presents for diagnosis may be the effect of long-term secondary effects. Mouse models, either naturally occurring or as a result of targeted mutagenesis or transgene insertion, can help analyse the processes underlying genetically caused infertility. However, they cannot be used directly in the case of $\mathrm{Y}$ chromosome deletions as the gene content of the human and mouse $Y$ chromosomes differ significantly. Indirect approaches are possible. The human $D A Z$ genes are part of a larger gene family with autosomal members. One of these is the Dazl gene (Yen et al., 1996; Seboun et al., 1997). The Boule/Dazl gene family has been studied in a number of organisms (Eberhart et al., 1996; Maegawa et al., 1999; Houston and King, 2000; Karashima et al., 2000) and in all cases is expressed in the germ line. Dazl is expressed in the mouse from at least embryonic day 12.5 and in the adult testis is found predominantly in spermatogonia and primary spermatocytes (Ruggiu et al., 1997). Consensus RNA motifs have been derived by three hybrid, selex, immunoprecipitation and gel shift approaches (Venables et al., 2001; Jiao et al., 2002; Maegawa et al., 2002). Possible in vitro targets are CDC25a and Tpx 1 but in vivo targets have not been defined. Targeted mutagenesis has been used to produce mice in which both copies of the gene are disrupted (Dazlko) and no Dazl protein is detectable (Ruggiu et al., 1997). These Dazlko mice are male and female sterile and an analysis of the developmental phenotype shows a loss of germ cells as meiosis starts. The final stage reached in the first wave of male meiosis is leptotene (Saunders et al., 2003). In adult animals few 
cells progress beyond the A-aligned to A1 transition (Schrans-Stassen et al., 2001). Germ cell transplantation has been used to test the function of mutant testes in a number of different systems (Boettger-Tong et al., 2000; Creemers et al., 2002; Noguchi et al., 2002). The present study investigated whether the Dazlko testes could support spermatogenesis of normal germ cells for two reasons. First, the Dazlko animals are not compromised other than in their fertility and offer the possibility of a well controlled source of germ cell recipients for transplantation experiments which have not been exposed to chemical- or radiation-induced ablation of stem cells. Second, this might point the way to the possibility of stem cell therapies for infertility caused by DAZ family mutations if the testicular niche remains functional.

\section{Materials and Methods}

\section{Animals}

Animal experimentation was carried out under project licence PPL60/2242 of the UK Home Office. Two types of recipient mice were used. Sterile Dazlko males (either C57Bl6dazl ${ }^{T m 1} \mathrm{hgu} / \mathrm{Tm}^{\mathrm{T}} \mathrm{hgu}$ or derived from a CBA dazl ${ }^{T m 1} 1 \mathrm{hgu/+} \times$ C57BL6 dazl ${ }^{T m 1 h g u /+}$ cross) between the ages of 8 and 14 weeks were identified by PCR genotyping and confirmed by visual observation at transplantation (testis is approximately $30 \%$ of the size of the testis of wild-type or heterozygous males). The second group of recipient males were wild-type C57BL6 (Charles River) treated at 4 weeks of age with busulfan (1 mg (30-40 g) $)^{-1}$ body weight) to destroy endogenous spermatogenesis (Brinster and Avarbock, 1994). These males were used for transplantation after a further 4-6 weeks.

Donor cells were obtained from transgenic ROSA males (CBA ROSA 26). The ROSA transgene was also crossed into the Dazl background so that animals homoor heterozygous for the ROSA transgene which were also heterozygote or knockout Dazl genotypes were available as donors or recipients. Testis cells from the ROSA stock express the Escherichia coli transgene $L a c Z$, and can be stained blue with X-gal (5 bromo, 4 chloro, 3 indolyl, D-galactosidase). These testis cells conveniently allow the identification of germ stem cell colonization and differentiation in both groups of recipient males and have been used previously for transplantation experiments (Boettger-Tong et al., 2000; Shinohara and Brinster, 2000).

\section{Cell preparation and transplantation}

Cells were extracted and transplanted as described by Boettger-Tong et al. (2000) with minor modifications. Germ cells from 4-6-week-old ROSA 26 male mice were obtained as a single cell suspension by enzymatic digestion of testicular tubules. Freed from the tunica, tubules were treated with collagenase (Sigma-Aldrich, Poole; type IV; $1 \mathrm{mg} \mathrm{ml}^{-1}$ ) in Hanks' balanced salt solution (Gibco-BRL, Paisley) for $15 \mathrm{~min}$ at $34^{\circ} \mathrm{C}$, with the addition of DNase I (Sigma-Aldrich; $0.07 \mathrm{mg} \mathrm{ml}^{-1}$ ) for a further $5 \mathrm{~min}$. After washing twice in HBSS, tubules were resuspended in HBSS plus trypsin (Sigma-Aldrich; $0.25 \mathrm{mg} \mathrm{ml}^{-1}$ ) and EDTA (Sigma-Aldrich; $1 \mathrm{~mm}$ ) for $10 \mathrm{~min}$ at $34^{\circ} \mathrm{C}$. Fetal bovine serum was then added to stop any further action of trypsin. Cells were filtered through a $40 \mu \mathrm{m}$ cell strainer (Falcon) to remove any remaining large debris, and centrifuged at $250 \mathrm{~g}$ for $5 \mathrm{~min}$ to pellet the cells. These were resuspended at concentrations between 15 and $30 \times 10^{6} \mathrm{ml}^{-1}$ in an injection media of Earle's balanced salt solution (GibcoBRL) and $5 \%$ fetal calf serum.

Testes were exposed under general anaesthesia induced by injection of $0.1 \mathrm{ml}(10 \mathrm{~g})^{-1}$ body weight of a solution of $30 \% \mathrm{w} / \mathrm{v}$ Hynorm and $15 \%$ Hynovell (Merial Animal Health, Harlow), and the efferent ductules minimally dissected as needed to make them accessible. In older animals (over 8 weeks old), fatty deposits make dissection of the ducts essential for injection. Cell suspensions mixed with Trypan blue $(0.5 \% \mathrm{w} / \mathrm{v}$, to aid in visualization of the suspension) were injected with micro-needles ( $40 \mu \mathrm{m}$ diameter tips) into the efferent ductules. Thereafter the fluid moved into the rete area of the testis and subsequently into the lumina of seminiferous tubules within the body of the testis itself. The testes of the C57BL busulfan-treated males, although smaller than those of untreated wild-type animals, could on occasion accept up to $25 \mu \mathrm{l}$ of cell suspension. The Dazlko testes, however, at best accepted $10 \mu \mathrm{l}$ of cell suspensions, presumably due to their reduced size compared with testes of wild-type mice. These volumes of cell suspension are approximately half the volume of dye solutions that can be injected. Internal blockage by the introduced cells may have played a part in the reduced volume of cell suspension that it was possible to inject. For general purposes 'fill' success was estimated as the percentage of surface tubules turning colour with the Trypan blue. As a routine, the right testis was injected, the left acting as a control. After injection the testes were returned to the body cavity, the abdominal wall and the skin was sutured and the animals were allowed to recover from anaesthesia.

\section{Analysis of transplants}

Recipient animals were killed between 10 and 23 weeks after transplantation. Testes were collected in media (Dulbecco's modified Eagle's medium), the tunica was removed and the tubules were teased apart with forceps. Tubules were fixed in $4 \%$ paraformaldehyde at $4^{\circ} \mathrm{C}$ for $1 \mathrm{~h}$, washed in three changes (30 min each) of PBS and stained in a buffered X-gal solution ( $1 \mathrm{mg}$ $\mathrm{ml}^{-1}$ ) overnight at $37^{\circ} \mathrm{C}$. The next day the tubules were washed in several changes of PBS and stored in $70 \%$ ethanol. Any areas of the seminiferous tubules that were stained blue were photographed (Fig. 1a), measured and 

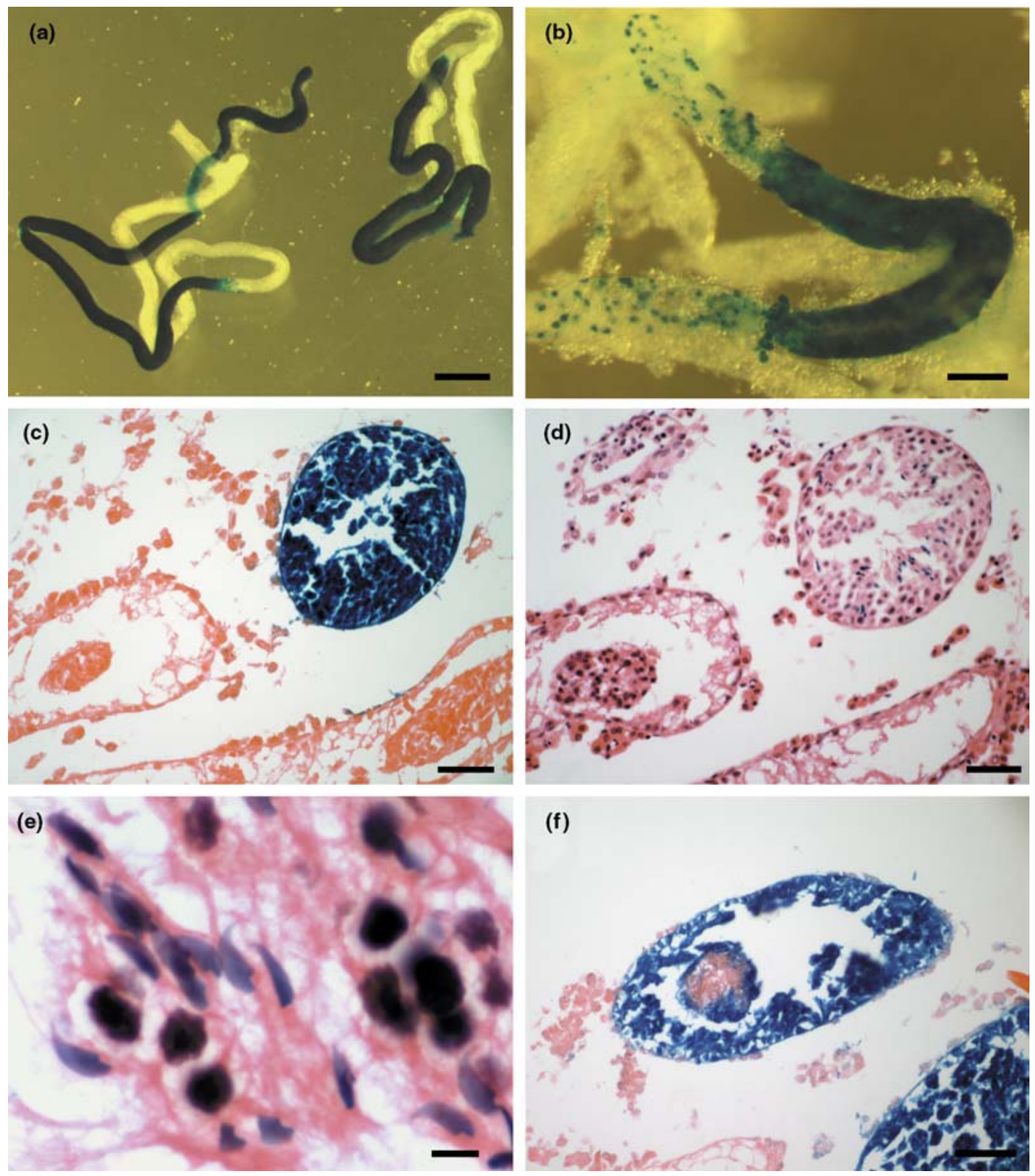

Fig. 1. (a) Dissected seminiferous tubules showing colonization by ROSA 26 mouse spermatogonial cells. (b) Proliferation of ROSA 26 cells at the extremities of a transplanted area into uncolonized areas of the tubule. (c) Section of dissected tubules from a Dazlko recipient showing colonized (blue) and uncolonized regions. (d,e) De-stained image of (c). Morphology of the tubule is partially restored where colonization has taken place. Higher power image (e) shows the presence of elongating spermatids in the colonized Dazlko tubule. (f) Tubule with Sertoli cell mass detached from tubule walls showing colonization with transplanted germ cells. Scale bars represent (a) $500 \mu \mathrm{m}$, (b) $200 \mu \mathrm{m},(\mathrm{c}, \mathrm{d}, \mathrm{f}) 50 \mu \mathrm{m}$ and (e) $5 \mu \mathrm{m}$. 
Table 1. Transplantation of ROSA donor cells into busulfan-treated mice and Dazl knockout mice

\begin{tabular}{|c|c|c|c|c|c|c|}
\hline Number & Strain & $\%$ surface fill & Days after transplant & Number of colonies & $\begin{array}{l}\text { Mean length of } \\
\text { colonies }(\mathrm{mm})\end{array}$ & Development \\
\hline \multicolumn{7}{|c|}{ Busulfan series $(n=13)$} \\
\hline B050 & $\mathrm{C} 57 \mathrm{BL}$ & 45 & 70 & 7 & 1.8 & Full spermatogenesis \\
\hline B055 & $\mathrm{C} 57 \mathrm{BL}$ & 85 & 70 & 3 & 2.8 & Full spermatogenesis \\
\hline B061 & $\mathrm{C} 57 \mathrm{BL}$ & 50 & 140 & 4 & 5.0 & $\begin{array}{l}\text { Full endogenous and } \\
\text { ROSA spermatogenesis }\end{array}$ \\
\hline \multicolumn{7}{|c|}{$\mathrm{DAZL}^{-/-}$series $(n=18)$} \\
\hline K004 & $\mathrm{C} 57 \mathrm{BL}$ & 50 & 90 & 3 & 2.6 & Full spermatogenesis \\
\hline K020 & C57BL & 40 & 76 & 3 & 1.5 & Full spermatogenesis \\
\hline K022 & $\mathrm{CBA} \times \mathrm{C} 57 \mathrm{BL}$ & 75 & 76 & 6 & 2.4 & Full spermatogenesis \\
\hline K024 & $\mathrm{CBA} \times \mathrm{C} 57 \mathrm{BL}$ & 40 & 76 & 1 & 5.0 & Full spermatogenesis \\
\hline KO25 & C57BL & 40 & 70 & 4 & 1.7 & Full spermatogenesis \\
\hline $\mathrm{KO} 26$ & C57BL & 70 & 70 & 3 & 1.5 & Full spermatogenesis \\
\hline
\end{tabular}

then processed further for histological analysis. X-galpositive and -negative regions were dissected, embedded in wax and $5 \mu \mathrm{m}$ sections were cut and mounted on tespar coated slides. In most cases the X-gal staining was too intense to allow identification of individual types of cell. This staining intensity was reduced by keeping alternate sections in xylene for $72 \mathrm{~h}$ at room temperature $\left(18^{\circ} \mathrm{C}\right)$. Both X-gal-stained and de-stained sections were then re-stained using haematoxylin and eosin, and cell morphology in areas that had already been identified as X-gal-positive was re-examined (Fig. 1c,d).

\section{Results}

Injections of ROSA donor cells were made into 15 C57BL busulfan-treated males (two died after transplantation) and into 16 Dazlko males, either on a C57BL6 $(n=10)$ or CBA $\times$ C57BL6 $(n=6)$ background (Table 1$)$. Of the 13 surviving busulfan-treated males, three showed colonization (23\%). Two of these males analysed at 70 days after transplantation contained all spermatogenic types of cell, including mature spermatozoa. The remaining male was left for 140 days after transplantation before being killed. This animal showed both full endogenous recovery in the control uninjected testis and $\beta$-galactosidase positive colonies with mature spermatozoa in the injected testis. Spermatozoa were also found in the epididymis, but differentiation between the transplanted and endogenously recovered spermatozoa was not possible on the basis of $\beta$-galactosidase staining due to high background staining.

In the knockout series, four out of 16 males exhibited colonies (25\%). Two of the positive males were C57BL dazl ${ }^{T m 1 / h g u / T m 1 h g u}$ transplanted with homozygous ROSA 26 donor germ cells, and two were $\mathrm{CBA} \times \mathrm{C} 57 \mathrm{~B} \mid$ dazl ${ }^{T m} 1 \mathrm{hgu} / \mathrm{Tm} 1 \mathrm{hgu}$, one transplanted with homozygous ROSA 26 germ cells and the other with heterozygous ROSA 26 germ cells. All of the males were analysed between 76 and 90 days after transplantation and for all males spermatogenesis had been restored in the injected testis and elongating spermatids could be clearly identified (Fig. 1e,f). Some areas showed mature spermatozoa (not shown). As the Dazlko males lack mature germ cells, the contrast between the regions colonized and uncolonized were clearly visible in these sections (Fig. 1c,d).

The percentage of animals showing colonization is comparable with previous reports (Brinster and Zimmermann, 1994; Parreira et al., 1998; Wistuba et al., 2002). There also appears to be little difference in frequency of colonization between the busulfan-treated and dazl ${ }^{T m 1 / h u / T m 1 / g u}$ males, although the numbers are small.

The length of developing colonies (Table 1 ) is lower but also comparable with previous reports (Nagano et al., 1999). A common feature of the testis of Dazlko males is the presence of clusters of Sertoli cells in the tubule lumen. Transplanted spermatogonia were in some cases able to colonize these clusters and germ cell maturation appeared normal despite not being located on the basement membrane (Fig. 1e).

\section{Discussion}

Germ cells and somatic cells represent distinct compartments of the testis, which are interdependent for proper function. However, this does not necessarily mean that one loses the capacity to function in the absence of the other. Transplantation of wild-type or mutant germ cells into mutant or wild-type testes has proved to be one way to test this possibility. This approach has been used previously to show that the unknown mutation in the juvenile spermatogonial depletion (jsd) mouse affects only the germ cells (Boettger-Tong et al., 2000; Ohta et al., 2001) and that although the CREM (cAMP response element modulator) gene product is expressed in both spermatids and Sertoli cells, the Sertoli cells are able to support spermatogenesis of transplanted 
wild-type germ cells (Wistuba et al., 2002) when their CREM gene function has been ablated genetically. The Steel/Kit system has also been used in this way (Ogawa et al., 2000). In the case of the Dazlko mice, as the present authors and others have previously shown that expression of the Dazl protein is confined to germ cells (Reijo et al., 1996; Ruggiu et al., 1997), it was hypothesized that their Sertoli cells might be unaffected by the absence of Dazl. However, because the Dazlko mouse is the best currently available model for the frequent AZFc deletions of the human $\mathrm{Y}$ chromosome, the present authors wished to confirm this by using spermatogonial stem cell transplantation. The present study demonstrates that the testis of adult Dazlko mice can support the production of spermatozoa by wild-type germ cells. The extent to which colonization occurs in these mice was compared with colonization in wildtype busulfan-treated animals. Although sample numbers were small there appears to be no major differences in colony number, size or presence or absence of spermatozoa. Stem cell enrichment procedures would likely enhance the extent and frequency of colonization. The implication in human terms is that the testes of AZFC mice may only be defective in germ cell function a conclusion supported by the relatively large number of AZFC individuals from which testicular spermatozoa can be isolated. It should be pointed out that $D A Z$ and Dazl functions may differ and that the AZFc deletion includes many genes in addition to the four copies of $D A Z$. These other genes are of unknown function and although expressed only in testis their expression pattern within the testis remains unknown and so could involve Sertoli cell function. In most reports germ cell transplantation recipients have been pre-treated with busulfan to eliminate host spermatogonial stem cells. This treatment has a number of drawbacks. The doses used have to be adjusted for different mouse strains and can be lethal for some animals; the response may be variable from animal to animal; and it is necessary to wait 28 days before the animal can be used. A less than optimal dose results in recovery of recipient spermatogenesis, which must be controlled for and may compete for available stem cell niches. The present authors suggest that genetically manipulated mice, Dazlko in particular, can be used as an alternative source of recipient animals for germ cell transplantation. This suggestion is not new; the jsd mouse has been put forward as a recipient and c-kit mutant animals would also be suitable. Although only one in four males will be Dazlko, the advantage of these animals is that unlike jsd mice they never produce spermatozoa and the mutation is not pleiotropic as is the case for c-kit mutations. In extensive investigation of these animals, the present authors have never observed cells beyond leptotene or early pachytene stages of meiosis. The present demonstration of the capacity of the testis of Dazlko mice to support spermatogenesis shows that these animals can be used without pre-treatment and without risk of resumption of recipient spermatogenesis. They provide a reproducible recipient that can be used at any age.

Rilianawati was a Wellcome Trust International Fellow; the Medical Research Council supported other authors. The authors would like to thank P. Saunders for critical review of the manuscript and the staff of the photographic department for help with illustrations.

\section{References}

Boettger-Tong HL, Johnston DS, Russell LD, Griswold MD and Bishop CE (2000) Juvenile spermatogonial depletion (jsd) mutant seminiferous tubules are capable of supporting transplanted spermatogenesis Biology of Reproduction 63 1185-1191

Brinster RL and Avarbock MR (1994) Germline transmission of donor haplotype following spermatogonial transplantation Proceedings National Academy of Sciences USA 9111 303-11307

Brinster RL and Zimmermann JW (1994) Spermatogenesis following male germ-cell transplantation Proceedings National Academy of Sciences USA $9111298-11302$

Creemers LB, Meng X, Den Ouden K, van Pelt AM, Izadyar F, Santoro M, Sariola H and de Rooij DG (2002) Transplantation of germ cells from glial cell line-derived neurotrophic factor-overexpressing mice to host testes depleted of endogenous spermatogenesis by fractionated irradiation Biology of Reproduction 66 1579-1584

Eberhart CG, Maines IZ and Wasserman SA (1996) Meiotic cell-cycle requirement for a fly homolog of human deleted in azoospermia Nature $381783-785$

Houston DW and King ML (2000) A critical role for xdazl, a germ plasmlocalized RNA, in the differentiation of primordial germ cells in Xenopus. Development 127 447-456

Jiao X, Trifillis $\mathbf{P}$ and Kiledjian $\mathbf{M}$ (2002) Identification of target messenger RNA substrates for the murine deleted in azoospermia-like RNA-binding protein Biology of Reproduction 66 475-485

Karashima T, Sugimoto A and Yamamoto M (2000) Caenorhabditis elegans homologue of the human azoospermia factor DAZ is required for oogenesis but not for spermatogenesis Development 127 1069-1079

Maegawa S, Yasuda K and Inoue K (1999) Maternal mRNA localization of zebrafish DAZ-like gene Mechanisms of Development 81 223-226

Maegawa S, Yamashita M, Yasuda K and Inoue K (2002) Zebrafish DAZ-like protein controls translation via the sequence 'GUUC' Genes to Cells 7 971-984

Nagano M, Avarbock MR and Brinster RL (1999) Pattern and kinetics of mouse donor spermatogonial stem cell colonization in recipient testes Biology of Reproduction 60 1429-1436

Nakayama $H$, Kuroda $H$, Onoue $H$, Fujita $H$, Nishimune $Y$, Matsumoto K, Nagano T, Suzuki F and Kitamura Y (1988) Studies of Sl/Sld in equilibrium with $+/+$ mouse aggregation chimaeras. II. Effect of the steel locus on spermatogenesis Development 102 117-126

Noguchi J, Toyama Y, Yuasa S, Kikuchi K and Kaneko H (2002) Hereditary defects in both germ cells and the blood-testis barrier system in asmutant rats: evidence from spermatogonial transplantation and tracerpermeability analysis Biology of Reproduction 67 880-888

Ogawa T, Dobrinski I, Avarbock MR and Brinster RL (2000) Transplantation of male germ line stem cells restores fertility in infertile mice Nature Medicine 6 29-34

Ohta H, Yomogida K, Tadokoro Y, Tohda A, Dohmae K and Nishimone Y (2001) Defect in germ cells, not in supporting cells, is the cause of male infertility in the jsd mutant mouse: proliferation of spermatogonial stem cells without differentiation International Journal of Andrology $\mathbf{2 4}$ $15-23$

Parreira GG, Ogawa T, Avarbock MR, Franca LR, Brinster RL and Russell LD (1998) Development of germ cell transplants in mice Biology of Reproduction 59 1360-1370 
Reijo R, Lee TY, Salo P et al. (1995) Diverse spermatogenic defects in humans caused by $Y$ chromosome deletions encompassing a novel RNAbinding protein gene Nature Genetics $10383-393$

Reijo R, Seligman J, Dinulos MB, Jaffe T, Brown LG, Disteche CM and Page DC (1996) Mouse autosomal homolog of DAZ, a candidate male-sterility gene in humans, is expressed in male germ-cells before and after puberty Genomics 35 346-352

Ruggiu M, Speed R, Taggart M, McKay SJ, Kilanowski F, Saunders P, Dorin J and Cooke HJ (1997) The mouse Dazla gene encodes a cytoplasmic protein essential for gametogenesis Nature 389 73-77

Saunders PTK, Turner JMA, Reynolds N, Ruggiu M, Taggart M, Burgoyne PS, Elliott D and Cooke HJ (2003) Effect of absence of mDazl on germ cell development at meiosis Reproduction 126 589-597

Schrans-Stassen BH, Saunders PT, Cooke HJ and de Rooij DG (2001) Nature of the spermatogenic arrest in Dazl -/- mice Biology of Reproduction 65 $771-776$

Seboun E, Barbaux S, Bourgeron T et al. (1997) Gene sequence, localization, and evolutionary conservation of DAZLA, a candidate male sterility gene Genomics 41 227-235
Shinohara T and Brinster RL (2000) Enrichment and transplantation of spermatogonial stem cells International Journal of Andrology $\mathbf{2 3}$ Supplement 2 89-91

Venables JP, Ruggiu M and Cooke HJ (2001) The RNA-binding specificity of the mouse Dazl protein Nucleic Acids Research 29 2479-2483

Wistuba J, Schlatt S, Cantauw C, von Schonfeldt V, Nieschlag E and Behr R (2002) Transplantation of wild-type spermatogonia leads to complete spermatogenesis in testes of cyclic $3^{\prime}, 5^{\prime}$-adenosine monophosphate response element modulator-deficient mice Biology of Reproduction 67 1052-1057

Yen PH, Chai NN and Salido EC (1996) The human autosomal gene DAZLAtestis specificity and a candidate for male-infertility Human Molecular Genetics 5 2013-2017

Received 15 May 2003

First decision 1 July 2003.

Revised manuscript received 4 July 2003.

Accepted 26 August 2003. 